\title{
Characterization and kinetics of surface area reduction during the calcination of dredged sediments
}

\author{
Jocelyn Ramaroson $^{\mathrm{a}}$, Jean-Louis Dirion ${ }^{\mathrm{a}}$, Ange Nzihou ${ }^{\mathrm{a}, *}$, Guy Depelsenaire ${ }^{\mathrm{b}}$ \\ a Ecole des Mines d'Albi-Carmaux, RAPSODEE UMR-CNRS 2392, Route de Teillet-81013 ALBI CT Cedex 09, France \\ ${ }^{\mathrm{b}}$ Direction Centrale de la Recherche Technologique SOLVAY SA, rue de Ransbeek 310, B-1120 Bruxelles, Belgium
}

Keywords:

Calcination

Sedimentation process

Toxic compounds

\begin{abstract}
A B S T R A C T
The deposit of sediment causes the silting of channels, rivers and lakes. This completely natural phenomenon is exacerbated by the introduction of industrial and urban wastes into the erosion and sedimentation process. Consecutively, other problems appear, such as flooding risks, decrease of biological purification capacity and associated loss of the biodiversity. The presence of toxic compounds (from industrial, household or agricultural origins) in the sediments worsens the situation, and requires curing to restore the natural environment and its function. This study assesses the technology to treat heavy metals from dredged sediments using phosphoric acid (The Novosol ${ }^{\circledR}$ Process, developed by Solvay) with the goal of converting metals, mainly $\mathrm{Pb}, \mathrm{Cd}, \mathrm{Zn}$ and $\mathrm{Cu}$ to insoluble metallic phosphates, and engineering properties (by calcination) of the final residues for the beneficial use. The effectiveness of the treatment was evaluated by performing the chemical reaction, followed by convective drying and maturation of the treated sediment at ambient temperature and finally calcination $\left(400{ }^{\circ} \mathrm{C}-1000{ }^{\circ} \mathrm{C}\right)$. This paper is focused on the calcination of the phosphated dredged sediment that destroys the organics and generates the particle size, specific surface area and the porosity changes of the treated sediment.
\end{abstract}

\section{Introduction}

Over the last century, degradation of harbours has resulted from extensive contamination of the associated sediments. The maintenance of waterways is of great concern in the USA as well as in European countries, as there is at present no satisfactory solution to the management of dredged sediments. The case of sediments is of particular interest, since large amounts of sediments are dredged to maintain harbour installations and keep rivers navigable. When the dredged zone is located near industrial, urban, or specialized sites, these sediments are in most cases polluted by heavy metals and organic compounds such as PAHs [1-3] and dioxins [4], that are harmful to the environment and may also be a threat to human health at high concentrations. Depending on their metal toxicity they will be either spread on agricultural land, confined or sent for chemical treatment [5]. In many cases, their spreading on land is consequently no longer possible for obvious safety reasons.

Consequently dredging of this material for channel maintenance and expansion presents a potentially enormous cost due to its removal, treatment, and ultimate disposal. Therefore, stabilizing metal pollutants and destroying organics from these sediments for either the beneficial reuse or safe storage is a very attractive option. There is

\footnotetext{
* Corresponding author. Tel.: +33563493222; fax: +33563493099.

E-mail address: nzihou@enstimac.fr (A. Nzihou).
}

a growing interest in stabilizing metals and destroying organic pollutants in these sediments and using them for the production of secondary materials. A technology to accomplish this objective is the treatment of raw dredged sediments with soluble phosphates followed by calcination, where the product has potential application in roadway pavements, concrete, and brick fabrication, as well as other potential applications. Solvay (a Belgian international company) has developed such a technology (The Novosol ${ }^{\circledR}$ Process) [6] to immobilize metal contaminants into hydroxyapatite $\left(\mathrm{M}_{5}\left(\mathrm{PO}_{4}\right)_{3} \mathrm{OH}, \mathrm{M}\right.$ : divalent metal) and decomposed organic pollutants; this treatment process has been optimized for numerous fly ashes, automobile shredder residues, and dredged sediments contaminated with both inorganic and organic contaminants throughout Europe. Incorporation of wastes into construction materials is a new field that is growing in many countries.

The potential utilization of the Treated Sediments as a base for the fabrication of construction materials, for rehabilitation of quarries, the building of waterway banks and paths, and fabrication of bricks, is being demonstrated, as well as the eco-compatibility of the final product in its final application. Experimental projects dealing with these issues are in progress in France, Italy and Belgium.

The current practice used for the management of contaminated dredged sediments is to store them in controlled watertight lagoons, but this is more and more restricted because of the associated effects on landscape, odor emissions, and because it does not address the risk that the polluted sediments pose in the long-term. Plants growing on 
the stored deposits have been tested for their potential to take up the pollutants, but here again it is not a pollution remediation but only a possible pollution transfer.

The objective of the technology is to immobilize heavy metals in sediments as a stable, low solubility, metal phosphate complex and then, if desirable, calcinate the sediments to produce usable materials with interesting physical properties (density, surface area, particle size) and destroy toxic organics.

The process consists of three successive stages: chemical treatment with phosphoric acid ( $3 \% \mathrm{wt}$ ), drying and maturation at room temperature, and a final thermal treatment between 400 and $900{ }^{\circ} \mathrm{C}$ The first stage is a liquid-solid reaction during which the sediment is brought into contact with a liquid reagent (phosphate). The objective of this step is the immobilization of heavy metals ( $\mathrm{Pb}, \mathrm{Zn}, \mathrm{Cu}, \mathrm{Co})$ and metalloids (As) in the form of insoluble metal phosphate precursors. These created phosphates are insoluble in a large range of $\mathrm{pH}$ and this represents a large improvement in comparison to hydroxides or salts metallic forms. The resulting chemical transformation creates a new phosphate compound in which the heavy metals are trapped as described in the simplified example below:

$10 \mathrm{~Pb}^{2+}+6 \mathrm{H}_{2} \mathrm{PO}_{4}^{-}+2 \mathrm{H}_{2} \mathrm{O} \stackrel{\text { precipitation }}{\longrightarrow} \mathrm{Pb}_{10}\left(\mathrm{PO}_{4}\right)_{6}(\mathrm{OH})_{2}+14 \mathrm{H}^{+}$

The second stage, drying and maturation of the sediment under ambient conditions of temperature and moisture, allows a decrease in the moisture. This is explained by progressive evaporation (caused by gas emission) of the moisture and maturation of the reaction products by continuation of the phosphoric acid neutralization and extending the stability of the final residues and structural changes.

The third stage (which is optional depending on the final use of the sediments and the presence of organic pollutants) is a calcination of the treated sediments at a temperature high enough to transform the metal phosphate precursors into still more inert crystalline compounds such as hydroxypyromorphite, $\mathrm{Pb}_{5}\left(\mathrm{PO}_{4}\right)_{3} \mathrm{OH}$ or Morelandite, $(\mathrm{Ba}, \mathrm{Ca}, \mathrm{Pb})_{5}\left(\mathrm{AsO}_{4}, \mathrm{PO}_{4}\right)_{3} \mathrm{Cl}$. In addition, during this step organic matter is eliminated by combustion and the final product is purely mineral in composition.

The latter stage is related to the sintering process that led to the porosity reduction, specific surface area reduction, particle size growth. This consequently reduces the environmental availability of the entrapped pollutants as confirmed by leaching tests performed when assessing the environmental impact [7].

This paper is focused on the calcination of the phosphated dredged sediment that destroys the organics and generates the particle size, specific surface area and the porosity changes of the treated sediment.

\section{Materials and methods}

\subsection{Preparation of sample}

The experiments were conducted with sediments from two different regions named sediment SV and SD. The samples used for the calcination were treated with phosphates in the NOVOSOL pilot unit located at Dombasles-sur-meurthe (France). The choice in sediments has been made relating to the industrial past of both regions. After collecting,
Table 1b

$\mathrm{Ca}, \mathrm{P}$ and Metal content $(\mathrm{mg} / \mathrm{kg})$ (dry)

\begin{tabular}{lllllll}
\hline Sample & $\mathrm{P}$ & $\mathrm{Ca}$ & $\mathrm{Cr}$ & $\mathrm{Cd}$ & \multicolumn{1}{c}{$\mathrm{Pb}$} & $\mathrm{Zn}$ \\
\hline Sediment SV $(\mathrm{mg} / \mathrm{kg})$ & 9269 & 14,584 & 196.9 & 15.3 & 823 & 2532 \\
Sediment SD $(\mathrm{mg} / \mathrm{kg})$ & 4539 & 52,987 & 218 & 38 & 1143 & 5438 \\
\hline
\end{tabular}

sediments were stored in closed plastic containers at $4{ }^{\circ} \mathrm{C}$ to reduce bacterial activity that could change their physical and chemical properties. In order to determine these characteristics, the French standard AFNOR [8] NF X 31-101 has been used. It consist of drying the sediment at $40{ }^{\circ} \mathrm{C}$ until total evaporation of the water content and stabilization of its mass, then on grinding and sieving at $2 \mathrm{~mm}$.

\subsection{Calcination procedure}

The sediment is introduced into an alumina crucible for a thermal treatment in a static furnace. The heating rate of $10{ }^{\circ} \mathrm{C} / \mathrm{min}$ was imposed from room temperature to the designated isotherm temperatures for the experiments (from 100 to $1000^{\circ} \mathrm{C}$ ). This temperature is maintained during $3 \mathrm{~h}$, after that it decreases until ambient temperature. Physical properties of the sediments, such as specific surface area and particle size distribution are then analysed.

\subsection{Chemical characterization}

The moisture, heavy metal and organic contents of the two sediments are presented in this section. The moisture was determined by drying the samples at $105{ }^{\circ} \mathrm{C}$ during 3 days. The metal concentration was determined according to the total digestion as proposed in the NFX 31151 French standard [8] followed by the dissolution of the solid with $100 \mathrm{ml}$ of distilled water and the analysis with the ICP-AES to determinate the metal concentration.

After removing calcium carbonate with $\mathrm{HCl}$ in a Thermo NA 2001 CHNS analyzer, the total organic matter rate was determined according to was performed using the French NF X31-409 Standard [8]. The chemical characteristics obtained are presented in Tables $1 \mathrm{a}$ and $1 \mathrm{~b}$.

\subsection{Physical characterization}

The specific surface area of the samples was determined using nitrogen adsorption with BET method (MICROMETRICS Gemini Vacprep 061). The solid density of the HAP was determined by helium pycnometry (MICROMETRICS, Accupyc 1330). The particle size distribution was determined using a MASTERSIZER 2000-HYDRO 2000 of MALVERN INSTRUMENTS analyzer. The true density is measured by a helium pycnometer (ACCUPYC 1330 of MICROMERITICS). The cell used is that of $10 \mathrm{~cm}^{3}$.

X-ray diffraction measurements (XRD) were carried out with $\mathrm{CuK}_{\alpha}$ radiation generated at $40 \mathrm{~mA}, 3^{\circ}<2 \theta<60^{\circ}$ range and at a scanning speed of $2^{\circ} / \mathrm{min}$. The phases present were determined by comparing the patterns with the JCPDS standards. The surface characteristics of the sediments (microstructure) was studied using environmental scanning electron microscopy (XL 30 ESEM-FEG, Phillips). The initial physical characteristics of the two sediments are presented in Table 2. Results obtained show that the sediment is mainly composed of silica, clay, feldspath and calcite.

Table 2

Characteristics of the sediments

Initial chemical characteristics of the sediments

\begin{tabular}{lllccl}
\hline Sample & \%moisture & $\mathrm{pH}$ & $\% \mathrm{C}_{\text {Total }}$ & $\% \mathrm{C}_{\text {Org }}$ & $\% \mathrm{C}_{\text {Inorg }}$ \\
\hline Sediment SV & 34.4 & 5.7 & 4.5 & 3 & 1.5 \\
Sediment SD & 34.4 & 5.9 & 17.5 & 11.7 & 5.8 \\
\hline
\end{tabular}

\begin{tabular}{llll}
\hline Sample & Density $\left(\mathrm{kg} / \mathrm{m}^{3}\right)$ & Size distribution $D_{50}(\mu \mathrm{m})$ & $\mathrm{Sp}\left(\mathrm{m}^{2} / \mathrm{g}\right)$ \\
\hline Sediment SV & 2.45 & 28 & 10.1 \\
Sediment SD & 2.45 & 28.6 & 10.6 \\
\hline
\end{tabular}




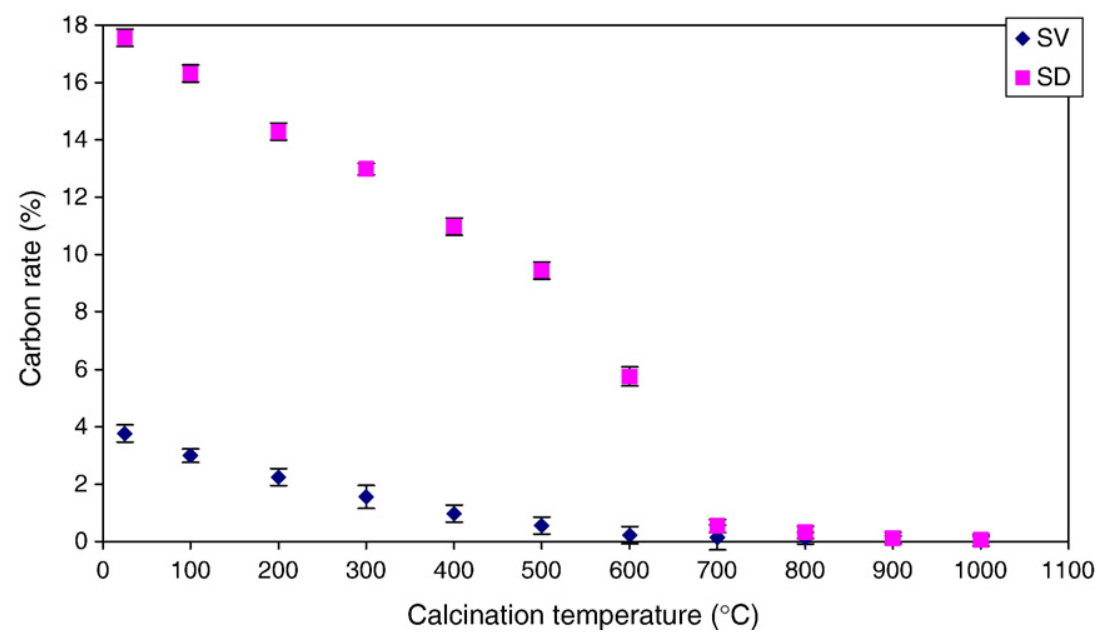

Fig. 1. Total carbon rate for the sediments SV and SD.

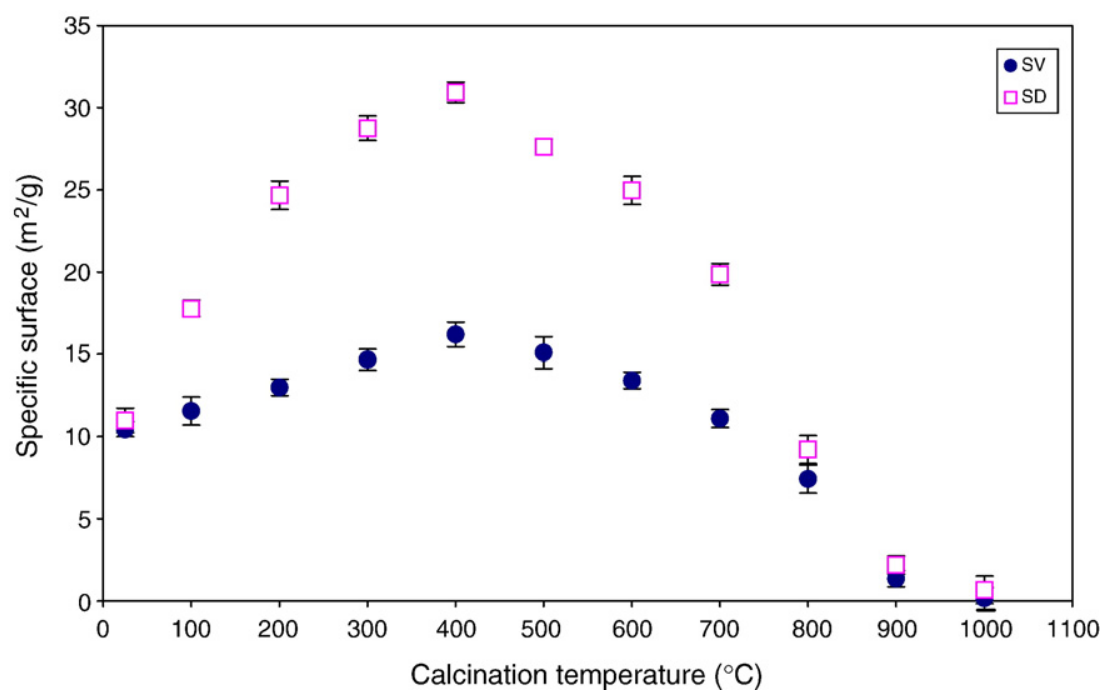

Fig. 2. Specific surface area versus calcinations temperature.

\subsection{Thermal characterization}

Differential scanning calorimetry (DSC) and thermogravimetry (ATG) were conducted simultaneously using a NETZSCH STA 409
PC instrument. These samples were heated from room temperature to $1000{ }^{\circ} \mathrm{C}$ at $10{ }^{\circ} \mathrm{C} / \mathrm{min}$ under Argon atmosphere.

The densification (linear shrinkage) of sediments was determined by Thermomechanical analyzer, TMA (TMA SETARAM SETSYS 16/18) on

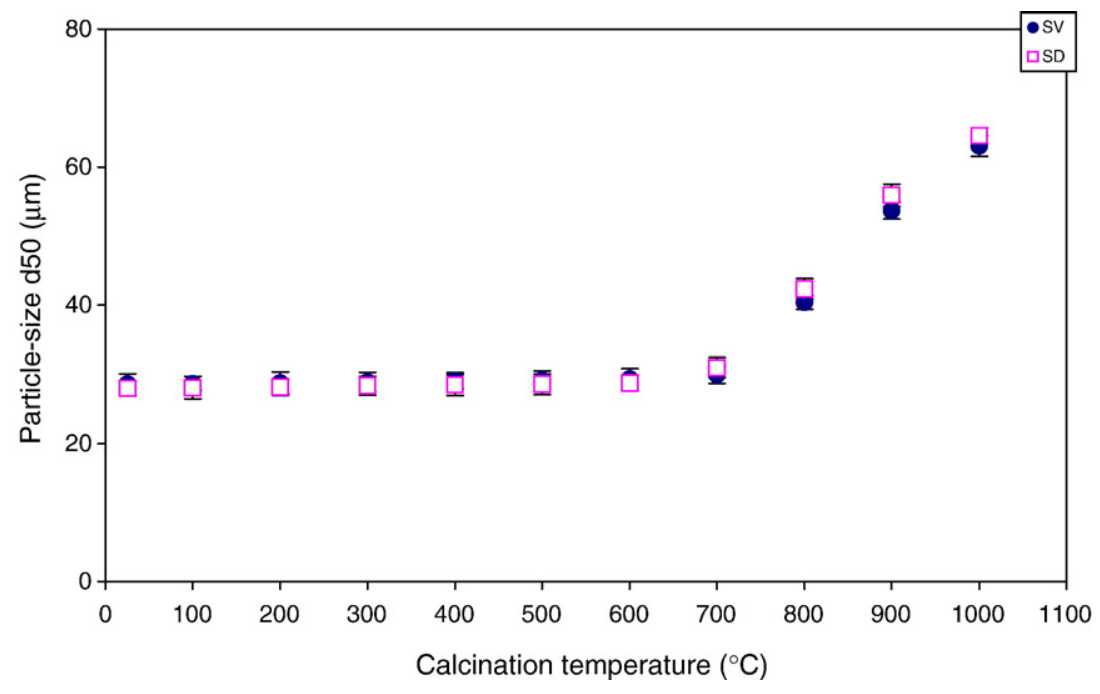

Fig. 3. Particle size growth with the calcinations temperature. 


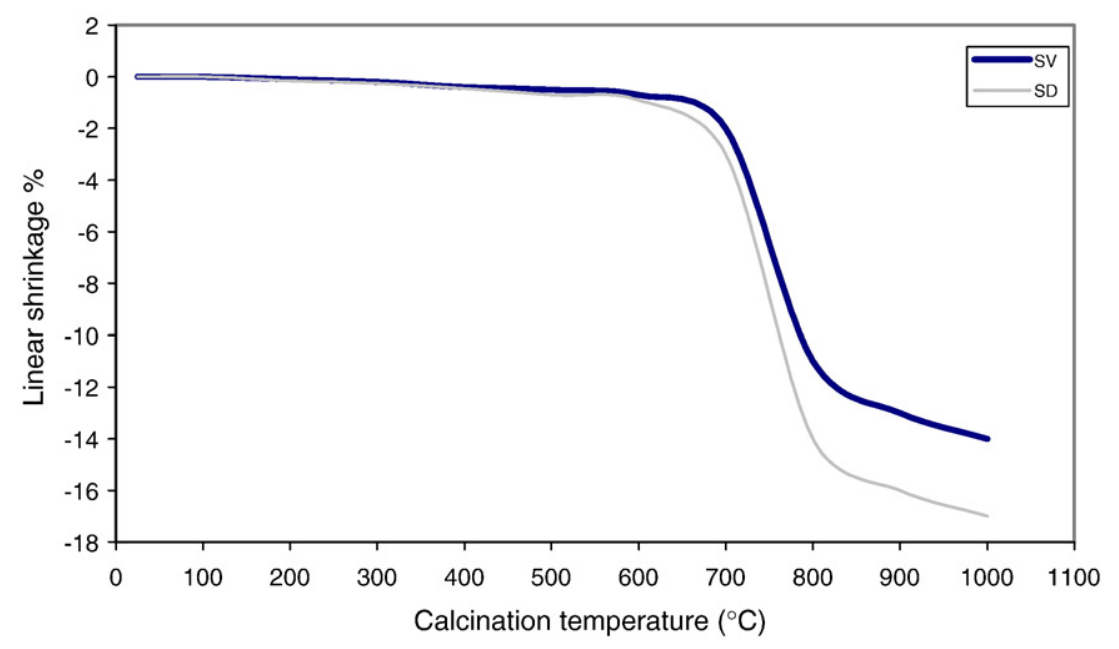

Fig. 4. Plots of shrinkage (\%) for the calcined sediments.

cylindrical samples. The samples were heated up to the temperature of $1000^{\circ} \mathrm{C}$ at a heating rate of $10^{\circ} \mathrm{C} / \mathrm{min}$. The ESEM micrographs when combined with the mass loss (TGA) and the TMA can provide excellent insight to the sintering process.

\section{Results and discussion}

The calcination of the phosphated dredged sediments has been carried out from room temperature to $1000{ }^{\circ} \mathrm{C}$. The most significant effect observed is the destruction of organics (Fig. 1) and the increase of the specific surface area. The TGA curves show the total destruction of organics at $700{ }^{\circ} \mathrm{C}$. This result is similar to that published by Hu et al. [9].

The trend observed could be explained by the decomposition of organics that results to the evaporation of $\mathrm{CO}_{2}$ and water vapour generating the creation of porous into the sediment. The consequence of such a phenomenon is the significant increase of the specific surface area that reaches the maximum at $400{ }^{\circ} \mathrm{C}$ (Fig. 2) for both sediments. The increase in the surface area is higher in the case of the SD according to the higher initial organic content (see Tables 1a and 1b).
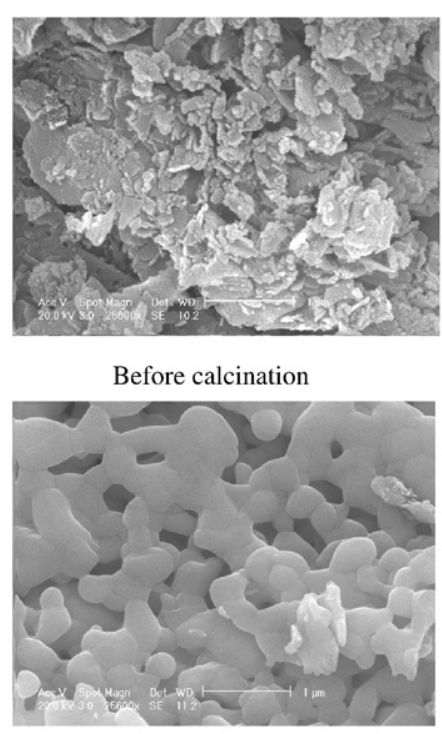

Advanced stage of sintering $\left(800^{\circ} \mathrm{C}\right)$

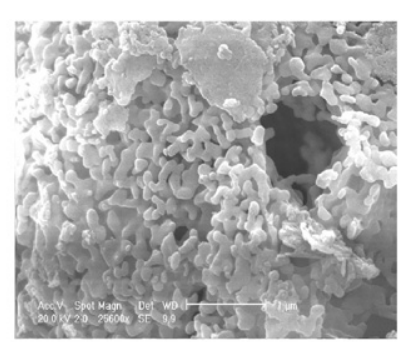

Calcination

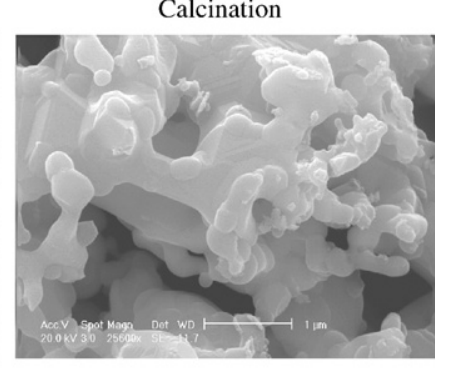

Melting observed $\left(900^{\circ} \mathrm{C}\right)$
Fig. 5. Environmental scanning electron micrographs for sintered sediments at different temperatures for $3 \mathrm{~h}$.
After $400{ }^{\circ} \mathrm{C}$, the results presented in Fig. 2 show a significant decrease of the surface area. It can be noticed that the decrease in surface is linked with the growth of sediment particles size as shown in Fig. 3.

These results could be explained by the sintering of phosphated mineral matrices well known in the literature at temperature higher then $600{ }^{\circ} \mathrm{C}[10-12$. Sintering occurs in three stages as described by White [13]. In the initial stage, the areas of contact between adjacent particles form and grow. In the intermediate stage, growing necks merge and the large number of small particles are replaced by a smaller number of large particles. This stage produces interparticle porosity whose surface may be inaccessible both to reactant gas during the reaction and to the nitrogen used to measure the specific surface area. In the final stage of sintering, the pore spaces become broken up with isolated closed pores remaining which shrink in size as densification proceeds [13]. Hence the sintering process is due to volumetric shrinkage at a constant mass as it can be observed in TMA analysis of the sediments presented in Fig. 4.

The shrinkage starts at $650{ }^{\circ} \mathrm{C}$ and continues up to the temperature studied $\left(1000^{\circ} \mathrm{C}\right)$ achieving $14 \%$ shrinkage for SV and $17 \%$ for SD. This fact is also manifested in environmental scanning electron microscope (ESEM) micrographs shown in Fig. 5. The surface of the particles is not

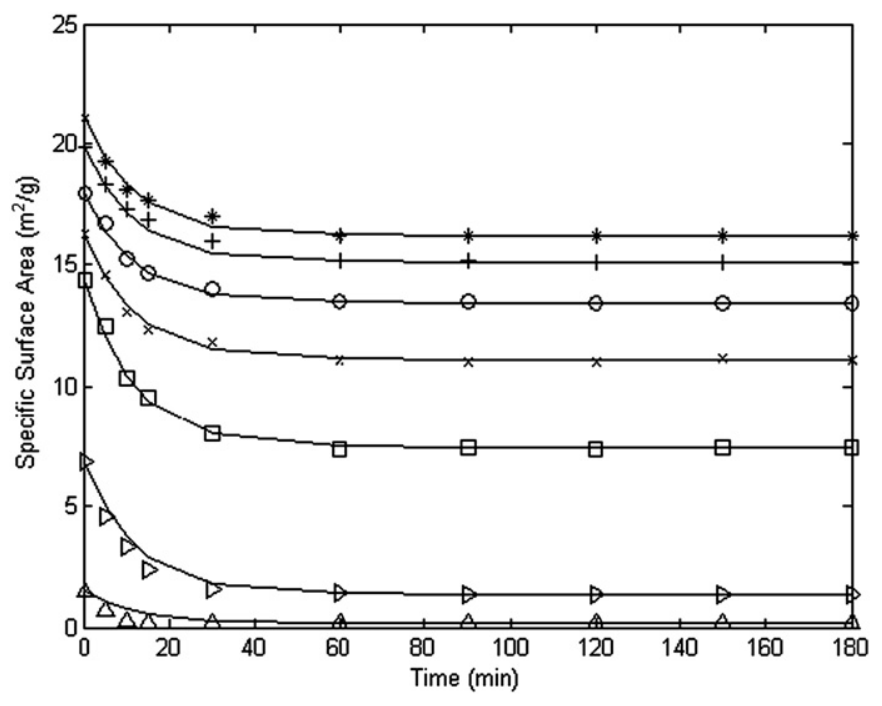

Fig. 6. Specific surface area versus time for sediment SV (_ : Nicholson model) and experiment at various temperature, ${ }^{*}: 400^{\circ} \mathrm{C},+: 500{ }^{\circ} \mathrm{C}, 0: 600{ }^{\circ} \mathrm{C}, \times: 700^{\circ} \mathrm{C}, \square: 800^{\circ} \mathrm{C}$, >: $\left.900{ }^{\circ} \mathrm{C}, \wedge: 1000{ }^{\circ} \mathrm{C}\right)$. 


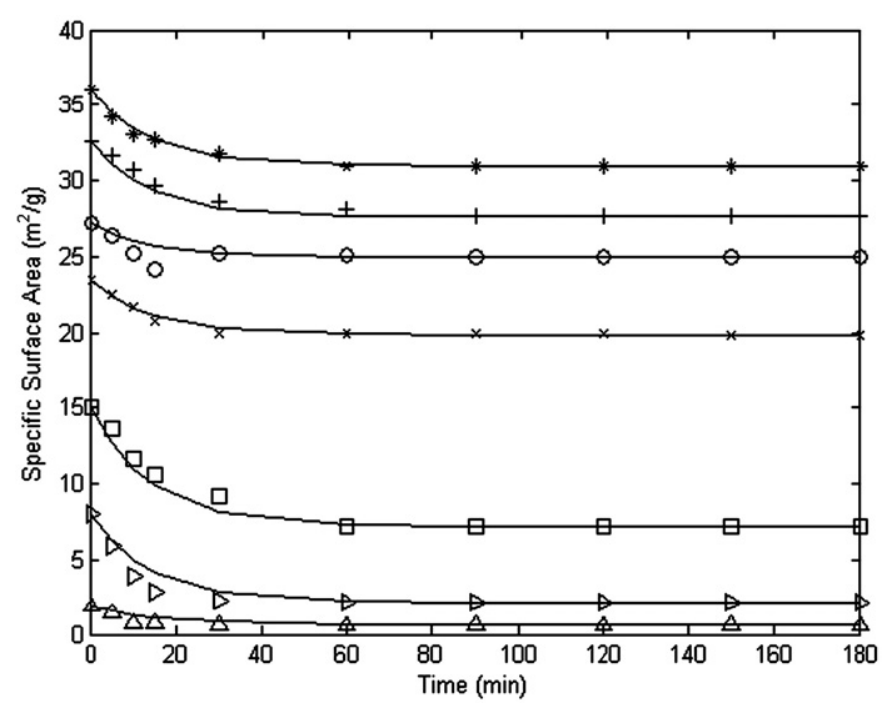

Fig. 7. Specific surface area versus time for sediment SD (__ : Nicholson model and experiment at various temperature, ${ }^{*}: 400^{\circ} \mathrm{C},+: 500{ }^{\circ} \mathrm{C}, 0: 600^{\circ} \mathrm{C}, \times: 700^{\circ} \mathrm{C}, \square: 800^{\circ} \mathrm{C}$, >: $900{ }^{\circ} \mathrm{C}, \wedge$ : $1000{ }^{\circ} \mathrm{C}$.

much compacted at room temperature. The surface appears to be compacted up to some extent at $700{ }^{\circ} \mathrm{C}$ while it is highly compacted and fused at $1000^{\circ} \mathrm{C}$. Only the results obtained for the sediment SV is presented since the similar observation was made with the sediment SD. The ESEM results corroborate well with Figs. 2, 3 and 4 that show the intensification of the sintering with the increase of the temperature. The rate of densification (rate of shrinkage not presented in the paper) reveals that the maximum shrinkage occurs at $1200^{\circ} \mathrm{C}$.

\subsection{Kinetics of specific surface reduction}

The specific surface area is one of the most reliable indicator of the sintering phenomenon because its kinetics of reduction is linked to the mechanism of the sintering and also that it is easily and reliably measured and the surface area reductions accompany all sintering mechanisms [14]. Various predictive models are available in the literature [15-19] for the quantification of the specific surface area as a function of sintering temperature and time. Recently, Bailliez and Nzihou [20] compared these models and found that the Nicholson [21] model [Eq. (2)] better predicted the kinetics of surface area reduction of phosphated solids. Hence, this model describing the relationship between surface area, time, and temperature is used in this study.

$\frac{\mathrm{d} S}{\mathrm{~d} t}=-K(T)\left(S-S_{\mathrm{e}}\right)$

where $S, S_{\mathrm{e}}$ and $K$ are respectively the specific surface area, the final and constant specific surface area and the rate constant. Generally, the rate constant depends on temperature.

Once the model assumed, the kinetic parameter estimation problem can be resolved. The minimization criterion $J$ used for parameters identification is given by the squared differences of the specific surface area as follows:

$J=\frac{1}{\operatorname{NexNm}_{i}} \sum_{i=1}^{\operatorname{Nex}} \sum_{j=1}^{N m_{i}}\left(\operatorname{Smod}_{i, j}-\operatorname{Sexp}_{i, j}\right)^{2}$

Nex and $\mathrm{Nm}_{i}$ respectively represent the number of isothermal experimental runs and the number of measurement for each run. Smod and Sexp are the theoretical and experimental specific surface areas. Since the Nicholson [21] model is defined with an ordinary differential equation, the numerical resolution of this problem consists in coupling a parameter estimation technique with a numerical integration technique.

The kinetics of surface area reduction at different sintering temperature starting at $400{ }^{\circ} \mathrm{C}$ are presented in Figs. 6 and 7. A good agreement is observed between the experimental results and the prediction using the Nicholson [21] equation for both sediments. As shown in these figures, the surface area is a strong function of temperature as well as time. For a given temperature, the surface area decreases very rapidly within the first 30 min and stabilizes there after. These figures further show the sintering temperature of $400{ }^{\circ} \mathrm{C}$ and sintering time up to $45 \mathrm{~min}$ do not change the specific surface area much. At $1000{ }^{\circ} \mathrm{C}$ and within $30 \mathrm{~min}$ the surface area reduces by $99 \%$ and reaches $0.97 \mathrm{~m}^{2} / \mathrm{g}$ which is almost the lower limit of the equipment. The trend observed is similar for the two sediments considered having different composition and characteristics. This observation is interesting for the use of such an equation to predict the sintering during the calcinations of treated dredged sediments.

However, the best rate constant in Eq. (2) was found to be independent to the temperature. We respectively found values of $8.4210^{-2} \mathrm{~min}^{-1}$ and $7.3210^{-2} \mathrm{~min}^{-1}$ for the rate constants of sediments SV and SD. A more detailed studies are in progress to confirm this result.

\section{Conclusion}

The study presented was focused on the understanding of the evolution of physicochemical properties of the dredged sediment treated with phosphoric acid during the calcinations from room temperature to $1000{ }^{\circ} \mathrm{C}$. The understanding of the evolution of these properties is of importance for the beneficial use of these materials in various fields. The results obtained show an increase of the surface area until $400{ }^{\circ} \mathrm{C}$ followed by a significant reduction accompanied by the particle size growth. Increase in surface area is attributed to the formation of porous due to the decomposition of organics. The evolution of properties is caused by the thermal sintering explained by the formation of necks and grain boundaries. The results presented also showed that the higher is the temperature the stronger is the sintering process leading to the surface area reduction and the particle size growth. A numerical model was used for the satisfactory prediction of the specific surface area decry.

\section{Acknowledgments}

The authors wish to express their gratitude to Solvay S.A for providing samples and for the financial support to this work.

\section{References}

[1] J.R. Miller, K.A. Hadson-Edwards, Heavy metal contamination of water, soil and sediment produced within riverine communities, Science of Total Environment 30 (2004) 189-209.

[2] L. Lei, A.P. Khodadoust, M.T. Suidan, H.H. Tabak, Biodegradation of sediment-bound PAHs in field-contaminated sediment, Water Research 39 (2005) 349-361.

[3] R. Rausa, G. Mascolo, Thermal treatment of sediments as function of temperature and reacting atmosphere, Journal of Analytical and Applied Pyrolysis 49 (1999) 425-445.

[4] I.-H. Lee, Y.-J. Wang, J.-M. Chern, Extraction kinetics of heavy metal-containing sludge, Journal of Hazardous Materials 123 (2005) 112-119.

[5] F. Marot, Characterization and treatment of the sediments of dredging containing of the metal pollutants, BRGM, Paris, 1998, p. 330.

[6] R. Derie, G. Depelsenaire, A. Nzihou, Procédé d'inertage de boue / Sludge treatment method, SOLVAY, 23/04/2004 FR2845983 \& WO2004035490.

[7] S. Kribi, Decomposition of the organic matter and stabilization of heavy metals in the dredged sediments, PhD thesis, INSA Lyon (2005) 220

[8] AFNOR Standard, Quality of grounds, 1999, p. 250.

[9] Z. Hu, R. Navarro, N. Nomur, H. Kong, S. Wijesekara, M. Matsumura, Changes in chlorinated organic pollutants and heavy metal content of sediments during pyrolysis, Environmental Sciences 1 (2007) 12-18.

[10] A. Nzihou, B. Adhikari, R. Pfeffer, Effect of metal-chlorides on the sintering and densification of hydroxyapatite adsorbents, Industrial \& Engineering Chemistry Research 44 (2005) 1787-1794. 
[11] P. Layvolle, A. Ito, T. Tateiohi, Sol-gel synthesis of amorphous calcium phosphate and sintering into microporous hydroxyapatite bioceramics, Journal of the American Ceramic Society 81 (1998) 1421.

[12] O. Prokopiv, I. Sevostianov, Dependence of the mechanical properties of sintered hydroxyapatite on the sintering temperature, Materials science and engineering 431A (2006) 218-227.

[13] J. White, in: G.C. Kuczynski (Ed.), Sintering and Related Phenomena, Gordon \& Breach, New York, 1967, p. 245

[14] R.M. German, Surface area reduction kinetics during intermediate stage sintering Journal of American Ceramic Society 61 (1978) 272-274.

[15] R.M. German, Z.A. Munir, Surface area reduction during isothermal sintering Journal of American Ceramic Society 59 (1976) 379-383.
[16] R.M. German, Z.A. Munir, Sintering and catalysis; Materials Sciences research 10 17] G.C. Kuzynski, Self-diffusion in sintering of metallic particles, Transactioon of AIME 185 (1949) 169-178.

18] C.Y. When, M. Ishida, Environmental Science \& Technology 7 (1973) 703.

[19] P.V. Ranade, D.P. Harrison, The grain model applied to porous solids with varying structural properties, Chemical Engineering Science 34 (1979) 427-432.

[20] A. Nzihou, S. Bailliez, Mechanisms of sintering of macroporous hydroxyapatite adsorbents, High Temperature Material Processes 21 (2002) 281-295.

21] D. Nicholson, Variation of surface area during the thermal decomposition of solids, Transactions of the Faraday Society 61 (1965) 990-998. 